\title{
(Para)Translations of Genji Monogatari over a millennium ${ }^{1}$
}

\author{
Gisele Tyba Mayrink Orgado e Daniel Serravalle de Sá*
}

\section{Introduction}

Written between the end of the tenth century and the beginning of the eleventh century, during the Heian period (794-1185), Genji Monogatari is one of the most celebrated literary texts of Japanese culture. Its authorship is attributed to Murasaki Shikibu. This millennial work is regarded as the first literary novel written by a woman in the world. Its importance goes well beyond Japan, taking its place in the so-called "western" literary milieu, especially after its wide dissemination in English and later in other European languages. The complexity of its style, with dialogues written in verse form and the colloquial use of terminologies and expressions of the time make the text challenging to contemporary readers.

Translations into modern Japanese, making this ancient text comprehensible to a contemporary readership, were crucial to updates of the work. Likewise, translations into other languages have helped overcome linguistic-cultural barriers for readers who do not speak Japanese. It will be argued here that the recent popularization of The Tale of Genji stems from this process of translating and from the paratextual elements about the translation procedures that usually accompany its translations. If on one hand, translations guarantee the survival of the text, on the other hand, they also modify it.

\footnotetext{
${ }^{1}$ Este artigo resulta de pesquisa realizada para o Trabalho de Conclusão de Curso de Bacharelado em Letras Inglês (2018), na Universidade Federal de Santa Catarina. Parte da referida pesquisa foi publicada no idioma português no periódico Ilha do Desterro (2019).

${ }^{*}$ Universidade Federal de Santa Catarina (UFSC).
} 
Thus, this paper presents some of the translation paths of this classic Japanese text in order to explain its reception in western countries and its literary recognition through its translations, focusing specifically on the editions published in English. The corpus consists of a modern Japanese version by Setouchi Jakuchõ (1996), and three editions in English, by Edward G. Seidensticker (1992); Arthur Waley (1993) and Royall Tyler (2001), all of which are direct translations from the classic Japanese novel.

Due to the differences between the cultures involved, considerations about the analysis of the translation process will be guided by Translation Studies theorists, specifically Gideon Toury (1995) and Antoine Berman (1991), who highlight the role of the translator as an (inter)cultural mediator. The theories presented by these authors propose that classic works, such as that of Murasaki Shikibu, require constant remodeling of their contents and concepts in order to be better understood by target audiences. Rather than simply translating words, both theorists assert that signification is expressed by means of chained utterances. To that end, some resources that accompany the translations, so-called editorial paratexts, according to Gérard Genette (1997), will also be used and will be amplified by José Yuste Frías's concept of paratranslation (2012).

\section{Translation: theoretical approaches}

Translation is part of any and all communication processes. As such, translation comprises transfering meaning from a source text (hereafter ' $\mathrm{ST}^{\prime}$ '), aiming to achieve similar reactions in the readers. From this point of view, the translator is key in the process of transmitting not necessarily the meaning of the words, but the message. However, the search for approximations and equivalent effects sometimes becomes unattainable, especially when source languages (hereafter 'SL') and target languages (hereafter 'TL') involve cultures that substantially differ from each other. In these cases, it seems that approximations should be encouraged, while not ignoring the cultural differences.

Until the 1970s, researchers considered translation as a product that was solely derived from another, or as a copy based on its original. More 
recently Itamar Even-Zohar (1990) and Gideon Toury (1995) have proposed different perspectives about translation. The latter, for example, proposes a new text-oriented approach - termed target oriented - that focuses on the target system, its language, and culture.

Toury argues that "Translations are facts of target culture; on occasion facts of a special status, sometimes even constituting identifiable (sub)systems of their own, but of the target culture in any event" (Toury 1995, p. 29). He proposes approaching the translation process not at its starting point - Source Language/Culture, but at the target point - Target Language/Culture. According to his perspective, it is the target culture that matters for the translation process, being the goal of the translation process.

In La Traduction et la Lettre. Ou l'auberge du lointain (1991), Berman prioritizes the letter - not only the words, but the poeticity, the rhythm, the alliteration, the 'colors' that accompany it - to the detriment of meaning. Berman states that a literary translation should not be restricted to the words of the text to be translated, but rather is an adjustment of the languages involved, a combination between the target structure and the perception of the original.

At first, Beman's and Toury's ideas may seem conflicting, given that one advocates taking the reader to the ST, while the other argues that translation should focus essentially on the target culture. However, in order to make communication between cultures possible, the translator should act as a mediator between both languages and cultures, and as a specialist in intercultural communication. Thus, considering that translation consists of "[...] a kind of activity which inevitably involves at least two languages and two cultural traditions [...]" (Toury 1995, p. 56), we can say that translation encompasses a mediation between cultures. If, on the one hand, translation minimizes visible differences when comparing one language to another; on the other hand, it also reveals these differences in their entirety, because it is precisely by the translation that one culture can glimpse the way other cultures speak and think, with all the flavors that are rightfully theirs.

\section{Paratextuality and (Para)Translation}


In Paratexts: thresholds of interpretation (1997), Genette systematizes elements for a definition of paratextuality. It is a theoretical-methodological model that enables us to circumscribe, examine and accurately highlight wellknown paratextual phenomena as well as new ones. The classification of paratexts optimizes the work of not only the translator but also of the readers, in the sense that paratextual materials explain strategies, criteria and delimitations within the objectives of a work of translation. In Tradución \& Paratradución (2006), Yuste Frías adds significantly to Genette's model, contributing greatly to fixing and expanding the concepts of paratextuality and paratranslation.

According to Genette, the paratexts that mediate a book to the reader, including elements within the book (peritext) and outside it (epitext), encompass: titles - and intertitles; the name of the author; epigraphs; prefaces and postfaces; notes - translation, explanatory, and footer; citations; glossaries; bibliography; illustrations, interviews, etc (Genette 1997, p. xviii).

If paratexts serve to describe, introduce and present texts, paratranslations are used to present the translations, situating their existence and ensuring their material presence in the publishing world. Paratranslation encompasses all that enables a translation to be published, i.e., to be realized and presented as a translation to the general public, more specifically, to its readers. It is thanks to the paratranslation that the reception and consumption of a translation is assured. Genette argues that there is no text without paratext, and that, likewise, there would not be a translation without its corresponding paratraduction or paratranslation (Yuste Frías 2006, p. 196-197).

For Yuste Frías, the main objective behind the conceptualization of paratraduction is to emphasize the function of paratextual elements in the translation process, namely to remind readers of the different ways in which these elements complement the text to construct the meaning of a published work. He goes on to state that, just as the paratextual elements contribute "to the structuring of the conception and representation of translation activities [...], paratranslation is what makes the translation appear as a complete translation in the publishing world", created "to analyze the time and space needed to translate any paratext that surrounds, wraps, accompanies, 
extends, introduces and presents the translated text" (Yuste Frías 2012, p. 118).

Also, conceptions and rules about the meaning of texts can vary from one period to another, from one cultural space to another and, consequently, from one language to another. Thus, the paratranslation concept presented by Yuste Frías has proven to be an indispensable resource for understanding the work of translating into other languages, including this case of translating from ancient Japanese into English.

\section{Murasaki Shikibu: Biography and work}

Murasaki Shikibu (aproximately 978-1016), to whom the authorship of Genji Monogatari is attributed, stands out in the literature of the Heian period (7941185). Lady Murasaki, as she is commonly known in the English-speaking world, lived most of her life amongst the imperial court in Kyoto, which was the capital of Japan at the time, and is now a Province, serving as a lady-inwaiting to Empress Akiko (Shõshi), second wife of Ichijõ Tennõ, 66 $6^{\text {th }}$ Japanese Emperor (980-1011). The name Murasaki, meaning purple or lavender, was apparently attributed to her because of the popularity of the character 'Wakamurasaki' (Chapter 5), one of Hikaru Genji's wives in the imperial court, which means "young Murasaki". She lived in the Imperial Palace for eight years and, during this period, she gathered stories and events around her, transforming them into material for Genji Monogatari.

The story, divided in 54 chapters, is structured in two parts: the first one, subdivided in two other parts, focuses on the main character Hikaru Genji. The second part presents the life of Kaoru, Hikaru Genji's son, with his stepmother, Fujitsubo. The narrative presents the life and loves of Prince Genji, the young, handsome and talented son of the Emperor with Kiritsubo, and his favorite consort, who became sick and died due to the contempt and hatred she suffered from the other consorts in the court. In an attempt to assuage his suffering, the Emperor marries Fujitsubo, with whom his son, Hikaru Genji, would later fall in love. The plot, thereafter, presents incestuous relationships, family conflicts, love games with male polygamy and female resignation, elements that make up the private life in the palace. 
There is a profound temporal, cultural and linguistic gap between the world of Genji Monogatari and the world we live in. Contemporary Japanese readers could not be expected to read and understand the content of the source work without prior study.

Therefore, one way to recognize the authenticity of the work in the context of the TL is by means of the paratextual elements that accompany the text. Explanatory notes (integrated with the ST) clarify some of the decisions taken during the interpretative and translation processes, which are key in the transference of meaning (communication) from a SL to the TL. Moreover, paratext acts as complementary annotations, comparable to a two-way street, preparing the reader to take a more conscious approach to the translated work.

The use of paratexts is even more necessary in works where comprehension depends on knowledge of the cultural, linguistic and historical background of texts, as in the case of Genji Monogatari. The paratextual comments in Genji address items such as musical instruments, court dresses, and even basic geography, which, while not considered crucial for the understanding of the text, nonetheless offer complementary information, expanding the reader's cultural knowledge of historical specificities linked to the Heian Japanese universe.

We have been discussing here the significance and the applications of paratextuality and (para)translation, particularly in relation to Genji Monogatari.

\section{Genji Monogatari's translations}

The work of Murasaki Shikibu is becoming better known thanks to translations that have been made over the years, both in Japanese and other languages into which it has been translated. The spatial and temporal distances separating Murasaki Shikibu's novel, written in medieval Japan, from current translations, lead to transformations motivated by linguistic and cultural implications that invariably reinforce the emergence of new interpretations and representations.

Many Japanese authors endeavoured to make Murasaki Shikibu's novel accessible to a general readership. The first intralinguistic translations 
into modern Japanese took place in the Meiji period (1868-1912), the most famous of which is signed by the poetess Yosano Akiko, who translated the work twice. Akiko's translation, made in 1912-1913, already had all 54 chapters that comprise the novel, but many were considered little more than summaries; consequently this edition is rarely read compared to her subsequent translation, published between 1938-1939 (Midorikawa 2003, p.193).

Another important translation is the work by Tanizaki Junichirõ, a novelist who translated Genji Monogatari three times, the first in 1939-1941, which was revised after WWII and published again in 1951-1959, and finally in 1964-1965. His first version was the object of political censorship and scenes that involved the character Fujitsubo and the Prince Genji were suppressed, since they were considered taboo at the time, being regarded as immorality among the imperial lineage (Shirane 2008, p. 292-293).

Currently, it is likely that the most widely read editions in modern Japanese are those published after Setouchi Jakuchõ's first translation. Regarding interlinguistic translations, the first cross-cultural translations of Genji Monogatari were done into English. In 1882, Suematsu Kenchõ initiated what would be the first version from Japanese to English, but the work was not completed. The translation only went as far as chapter 17 (Midorikawa 2003, p. 194), so it is not considered a full translation, although it was the first attempt.

After him, three other major authors worked extensively on translations directly from Murasaki Shikibu's novel. The first was Arthur Waley, whose translation The Tale of Genji - A novel in six parts was published in 1933. Although his publication was heavily criticized, mainly because of its option for a freestyle translation (Puette 1983, p. 56), it was nevertheless recognized as a significant collaboration, given that it introduced the work of Murasaki Shikibu to the western world. After that, translations to languages other than English started to be made and other countries and cultures were introduced to Genji by means of indirect translations made from Waley's publication. At the time of his translation, Waley did not have much access to references, bibliographies or dictionaries, so it was expected that the next generation of translators, supported by new 
resources and pieces of research, would seek to improve some aspects in the subsequent translations of Genji Monogatari.

In 1976, Edward G. Seidensticker attempted to correct the 'flaws' pointed out in Waley's translation. His edition is based on postwar research about Japan and his translation became widely read outside of Japan, even being used as an academic text in English-speaking universities. In spite of the popularity attained by Seidensticker's translation, the one made by Arthur Waley continues to be published and, just as the modern Japanese translations of Yosano Akiko and Tanizaki Junichirõ represent two different approaches to the original, Waley and Seidensticker's English translations represent different choices for readers (Midorikawa 2003, p. 194). Seidensticker adopts a method of translation that prioritizes the ST. However, to bridge both cultures, he translates the names of the characters into English.

The third translation into the English language discussed in this paper is Royall Tyler's (2001-2002), who, in addition to seeking to preserve the content from the ST and the historical-cultural context, does not assign names to the characters, but rather, their titles. Still, seeking to better explain what might cause the 'foreignness', to use Antoine Berman's expression, Tyler offers several footnotes throughout his work, adopting, in practice, a procedure similar to that proposed by Genette, in the sense that the main function of the paratextual notes is to convey information about the text. The publication of Tyler's translation provided readers with a third English version of Genji Monogatari and, as a whole, these three examples serve to reflect upon how translators, both to English and to modern Japanese, dealt with the distinct characteristics and challenges brought by the ST (Midorikawa 2003, p. 195).

Currently, there are publications of Genji Monogatari in several other languages, including Spanish, French, Italian, Arabic, European Portuguese (under the title of O Romance de Genji), besides German, Russian, Chinese, Korean, among others, reaching an estimated total of 30 languages so far, 
including some publications in Braille ${ }^{2}$. However, it is worthy of note that Genji Monogatari has not yet been published in Brazilian Portuguese.

In addition to English translations, there are some other translations that stem from the ST in classic Japanese, including the German edition by Oscar Benl (1966), the French edition by René Sieffert (1978-1985), and the Italian edition by Maria Teresa Orsi (2012), as well as many 'retranslations'. In short, Genji Monogatari is a work that has translations that do not stem from the classic Japanese manuscripts but from English translations (indirect translations), as is the case of most of the editions currently available.

Considering all the complexities involved, due to the culturallinguistic differences between Japanese and other western languages, and also in relation to the issues that are intrinsic to the work, it is likely that in proposing translations into other languages, some of these aspects have undergone changes when translated indirectly.

Analyzing the texts reveals that, according to the first lines of Murasaki Shikibu's text by the three English-language translators, there is no consensus, attempt at uniformity or textual standardization.

\section{Table 1: English Translations}

\begin{tabular}{|l|l|}
\hline $\begin{array}{l}\text { The Tale of Genji } \\
\text { Edward G. Seindesticker (1992) }\end{array}$ & $\begin{array}{l}\text { In a certain reign there was a lady not of the first rank } \\
\text { whom the emperor loved more than any of the others. }\end{array}$ \\
\hline The Tale of Genji & $\begin{array}{l}\text { At the Court of an Emperor (he lived it matters not } \\
\text { when) there was among the many gentlewoman of the } \\
\text { Wrthur Waley (1993) }\end{array}$ \\
\hline The Tale of Genji & very high rank was favoured far beyond all the rest; ... \\
Royall Tyler (2001) & $\begin{array}{l}\text { In a certain reign (whose can it have been?) someone of } \\
\text { and Intimates, enjoyed exceptional favor. }\end{array}$ \\
\hline
\end{tabular}

\footnotetext{
${ }^{2}$ Source: Worldcat, www.worldcat.org. Retrieved on: 10 May 2019.
} 
Given that they are distinct works of translation, written by different authors, spatially and temporally separated - from the ST and from each other - no textual equality or similarity can be expected, since each translator has his own style, interpretation of the original, individual background, either offering the reader a text that approaches the referential base, thus respecting the ST - Seidensticker and especially Tyler - or privileging the target text (hereafter ' $\mathrm{TT}^{\prime}$ ') - a solution proposed by Waley.

Regarding the intralingual translation into modern Japanese, even though it is the same language, Setouchi Jakuchõ also incurs the foreignizing translation $^{3}$, given that she redrafts the work with an aim to preserve the main characteristics of the ST. As an example, Setouchi Jakuchõ maintains in the beginning of the narrative references to the 'reign of the Emperor' as something not to be specified or established:

\section{Table 2: Japanese Text}

\begin{tabular}{|c|c|}
\hline $\begin{array}{l}\text { 源氏物語 } \\
\text { (Setouchi Jakuchõ, 1996) }\end{array}$ & $\begin{array}{l}\text { Genji Monogatari } \\
\text { (Transliteration) }\end{array}$ \\
\hline 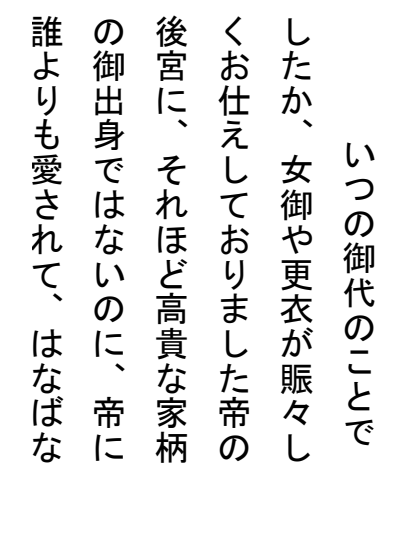 & $\begin{array}{l}\text { Itsu no miyo no koto deshitaka, } \\
\text { nyõgo ya kõi ga niginigishiku } \\
\text { otsukaeshite orimashita mikado } \\
\text { no kõkyũ ni, sorehodo kõki na } \\
\text { iegara no goshusshin dewa nai } \\
\text { noni, mikado ni dare yori mo ai } \\
\text { sarete, hanabanashiku, yũgũ } \\
\text { sarete irassharu kõi ga } \\
\text { arimashita. }\end{array}$ \\
\hline
\end{tabular}

\footnotetext{
${ }^{3}$ A term used by Lawrence Venuti (The Translator's Invisibility, 1995) to designate the type of translation in which a TT is produced which deliberately breaks target conventions by retaining something of the foreignness of the original. Source: MARK, S. \& COWIE, M. Dictionary of Translation Studies. UK, Manchester: St. Jerome, 1997; p.59.
} 
Setouchi Jakuchõ's edition keeps the when of the fact she is going to tell unknown, as well as in which reign that fact would have happened, as seen in the first line Itsu no miyo no koto deshitaka. Free form translation: [In the reign of which time (happened?)]. This part of the text was omitted by Seindesticker, while Waley [he lived it matters not when] and Tyler [whose can it have been?] attempted to convey the idea to English language differently, with Tyler mantaining the question structure that is found in the ST. In connection with Toury's ideas, namely, that it is the target culture that matters most in the translation process, the authors choose either to suppress or explain the Japanese expression, seeking to achieve the desired effect in the TL.

In the excerpt above, a reference is also made to the fact that the lady in question is the Emperor's favorite consort. Free form translation: [In the wings of the imperial palace, the ladies consorts Nyõgo and Kõi served vividly, there was, however, a lady who, although not of the high nobility, was more beloved than all the others and, in a glamorous way, was favored by the Emperor in his treatment]. By making use of this foreignizing translation strategy, it is possible to perceive that Setouchi Jakuchõ works in a similar way to the other translators, despite the difference between their languages.

Throughout this research it has been argued that distances between the texts go beyond linguistic contrasts of semantic and/or lexical character, to include paratextual and aesthetic presentation. In order to translate paratextual resources, the translation professional ought to develop a skill that is often neglected, and which Riitta Oittinen calls "visual literacy" (Yuste Frías 2012, p. 120). The visual aspect of a literary work cannot be restricted to the forms and colors of iconic paratexts presented in the publication. According to Yuste Frías (2012), Oittinen refers to a much broader visual approach than simply words and figures, encompassing the entire visual appearance of the book, which includes phraseological structures, book covers, and even the punctuation adopted, since each typographical character, its size and style, contributes not only to the readability of the translation, but also to the success - or failure - of the 
publication. However, the first paratext that is generally seen in a book is its cover and title.

We will discuss the similarities and diferences in the use of some paratextual elements and resources in Genji Monogatari, especially focusing on the translations by Seidensticker, Waley and Tyler.

Among the analyzed editions, it was possible to find different modalities of visual presentation. In Japanese-language publications, most editions of Genji Monogatari are published as hardcover volumes, lined with fabric in discreet colours such as maroon, green or dark blue, containing the title and volume of the work, in addition to the name of the author/translator, on the front and on the spine, as can be observed in the editions by Yosano Akiko (1969); Tanizaki Junichirõ (1961); Setouchi Jakuchõ (1996); and also in the classic Japanese work, dated $1654^{4}$.

In Setouchi Jakuchõ's (1996) intralingual edition, although the author makes use of paratextual resources for the benefit of contemporary readers, there were no different approaches regarding the cover, title, intertitles, i.e., the "title page" (or 'flyleaf') that precede the beginning of the actual text. As a typical characteristic of Japanese society, in which beauty lies in simplicity, Jakuchõ adopts a minimal, basic way by simply using the ideograms that correspond to Kiritsubo in the first chapter of the work.

However, considering the degree of complexity related to the number of characters, their designations and roles played in the narrative, the inclusion of further elements was needed to clarify to the modern reader aspects that could otherwise hinder the understanding of the narrative. Although no specific appendix was inserted, some paratextual elements were included such as: Genji no shiori - yakusha kaisetsu (p. 266), approximately [Genji's Guide - Translator Comments]; sankou zuroku (p. 279), in free translation [Illustrative references]; in addition to goku kaishaku (p. 296), which serves as an explanation or interpretation of the expressions - a glossary. Regarding the anthroponyms, as it is an intralinguistic work, there was no attempt to translate names or titles because there was no need, although the author provides an appendix with an explanatory list of who

\footnotetext{
${ }^{4}$ Source: Biblioteca Digital Mundial (www.wdl.org/pt).
} 
are the characters in the plot, omo na tõjõ jinbutsu (p. 8), that is, a list referencing the [Main characters].

In spite of the criticism that Arthur Waley's seminal translation (19251933) received for being a freestyle translation, it also obtained great recognition especially for being the pioneering translation that brought the work of Murasaki Shikibu to the western world. The external presentation of the Waley publication, with its 6 volumes, followed the same proposal as the Japanese editions, that is, a traditional hardcover lined with fabric in discreet tone, complemented with an additional illustrated cover.

Regarding the European editions' covers, including those in languages other than English, a standard of covers with beautiful and delicate illustrations is followed by the publishing houses, as can be seen in Seidensticker's translation. In Tyler's edition we find the same project as the versions of Setouchi Jakuchõ and Waley, as his edition was released in hardcover lined with fabric, overlayed with illustrated paper.

The same principle was applied to the title, adopting the standard 'place' reserved for titles (Genette 1997, p.65). Moreover, regarding the other paratexts used by Tyler, the intertitle appears in the "title page" (or 'flyleaf'), written in romanized Japanese, accompanied by its translation "Kiritsubo: The Paulownia Pavilion", followed by an explanation of the meaning of the ideograms that make up the term Kiritsubo, and clarifications about the word.

The title as a resource is a unique paratextual element, which acts as an invitation to read, stimulating a previous interpretation of the text and representing the magnitude of the literature at hand. It is possible to find not only several definitions that characterize the titles, but, above all, the place they will occupy (Genette 1997, p.55-65); the moment of their appearance; in addition to its addressers and addressees. If the text is the object of the reading, the title, as well as the name of the author, is the object of circulation.

In literature, it is possible to find examples of translated titles that greatly differ from their counterparts. However, amongst the versions of Genji analyzed, this was not the case, since translators, despite the different languages and cultures, opted for a literal translation of Genji Monogatari, with the exception of Arthur Waley who deliberately proposed a longer title 
- The Tale of Genji: A novel in six parts: The Tale of Genji; The sacred tree; A wreath of cloud; Blue trousers; The lady of the boat; and The Bridge of Dreams, respectively.

Unlike the main title, which reaches beyond the circle of readers, the intertitles are accessible only to those who have browsed the text. Additionally, unlike the general title - which is indispensable to the material or social existence of the book - intertitles are not considered an absolute condition for the existence of a text. Though not mandatory, it should be noted that there are cases in which their absence may cause uncertainty and misuderstandings (Genette 1997, p. 294), leading the reader to believe that the text is a continuous narrative when it is not, as it is the case with Genji Monogatari.

In the case of the intertitle of the chapter Kiritsubo, there was no agreement amongst the translators. However, an important observation about the intertitles in Arthur Waley's translation concerns the omission of a chapter - number 38, Suzumushi, translated by both Seidensticker and Tyler as The Bell Cricket (Puette 1983, p. 56).

As to the use of annotations, although Waley adopted a freestyle of translation in his edition, the Kiritsubo chapter, for example, has as many footnotes as in Seidensticker's edition, and substantially fewer than in Tyler's third translation. In Waley's translation, there are only 17 footnotes throughout the 16 pages that comprise the first chapter.

Compared to Tyler, Seidensticker has made modest use of this resource. Throughout the 14 pages of the first chapter, Seidensticker did not exceed two footnotes per page. In total, only 16 footnotes were used in the chapter Kiritsubo. In Tyler's edition, as previously mentioned, the author sought to maintain the ST as well as the historical-cultural environment of the narrative. However, for this to be possible without causing 'foreignness' (Berman) to the reader, the translator uses the paratextual procedures as proposed by Genette, including several resources presenting, mainly, numerous footnotes throughout his work.

It has been argued that the use of notes as a textual support allows translators to explain their decisions about the translation and to clarify their responsibilities to themselves and readers. In Tyler's edition, the Introduction 
begins with an explanatory note which states that, although The Tale of Genji was written 1000 years ago, it is the translator's opinion that any reader can appreciate the work these days, adding that "The notes are useful but not required" (Tyler 2001, p. xi). The statement creates a certain sense of incongruity, given that in making use of the note, "the translator is assessing the need for the clarification he intends to provide and automatically judging the capacity of the reader to understand the text" (Lyra 1999, p. 74).

In the case of the three translators discussed here, the one who most frequently adopts the footnote as a textual resource is Tyler, although he deems them useful, but not essential. Among the 15 pages of text that make up the first chapter of his translation - Kiritsubo - Tyler employs numerous footnotes on every page, totalizing 65 footnotes for this chapter alone.

When compared instrinsically, the contents of such footnotes are considerably different in their nature. For example, Waley's first footnote is advisory, instructing the reader on how the chapter should be read/interpreted: [This chapter should be read with indulgence. In it, Murasaki, still under the influence of her somewhat childish predecessors, writes in a manner which is a blend of the Court chronicle with the conventional fairy-tale]. Moreover, his second footnote introduces Ming Huang as a Famous Emperor of T'ang dinasty in China; lived A.D. 685-762, while, in his text, Tyler mentions Ming Huang as the one to whom the court lady Yang Kuei-fei was related (Waley 1993, p. 7).

Differing from Waley's edition, in the Japanese text the main reference is made to the Lady, instead of the Emperor, which Tyler mantains in his translation by preserving the Japanese term Yõhiki, with the following footnote: The beauty Yõhiki (Chinese Yang Guifei) is infatuated by the Chinese Emperor Xuanzong (685-762) who neglected the state provoked a rebellion, and his army forced to be executed. Bai Juyi (772-846) told the story in a long poem, "The Song of Unending Sorrow" (Chinese "Changhenge", Japanese "Chõgonka", Hakushi monjũ 0596), which was extremely popular in Heian Japan. (Tyler 2001, p. 3). I have cited here three examples of the diversity of themes and subjects Tyler discusses in his footnotes, illustrating the role and the uses of paratextual resources in translations. 
Seidensticker's translation refers to the Lady Yang Kuei-fei, without adding any note about it - neither referring to her nor to the Emperor of China. His first footnote appears only in the following page, to clarify that the young Prince is 3 years old and according to the Oriental system: * All ages are by the Oriental count, not of the full years but the number of years in which one has lived. Thus it is possible to have a count of three after one full year and two days, one at the end and one at the beginning of another year. All ages are either one or two above the full count (Seindensticker 1992, p. 8). This is an example of a footnote being used to explain a cultural difference rather than the meaning of a word or a linguistic expression.

One way or another, in the case of languages of different etymological origin, such as Japanese $\Leftrightarrow$ English, this resource is where the the translator intends to share and enrich the content of what is read. Keeping the original term in a translation characterizes "an attitude of respect for the foreign language and culture", often so profound that the translator does not hesitate to go beyond the limits of his own language, "in order to preserve something of the other's quality, strange, foreign" (Britto 2010, p. 139).

\section{Final remarks}

Despite discussing a relatively small sample of Genji Monogatari, this paper has addressed some linguistic and paratextual differences between the text in modern Japanese and three translations into English by Arthur Waley (1933), Edward G. Seidensticker (1976) and Royall Tyler (2001), evidencing the difficulties, often expressed by the translators themselves, as they faced the challenge of translating two very distinct languages/cultures. We also presented Setouchi Jakuchõ intralingual translation in order to compare the resources and strategies used by the translators. It was also argued that these works introduced and popularized Genji Monogatari among a western readership. Moreover, we used a select number of paratextual elements found in the narrative and in its translations - or paratranslations - to illustrate the value of these resources in the comprehension of Murasaki Shikibu's novel. 
As a cornerstone of the text and the context, culture is an inseparable component of languages. According to Gideon Toury's theories, when translating a language, the culture is also translated.

Therefore, both language and culture deviations from the ST would be noticeable in the target system, as deviations from the TT could occur in function of the way information and forms were introduced into the new system from the translation of texts. In this sense, the cultural question is located at the central base that supports the translation.

In the case of Genji Monogatari and its translations, where the realities are distant in time and space, cultural imbalances are striking. The paratranslation acts here as a resource in which the historical-literary recomposition allows translators to recreate and make more accessible an important part of the linguistic, political and anthropological features which arise from the encounter between different cultures. Paratextual resources, developed by the translator or by external collaborators, optimize the process of reception and representation performed by the reader, particularly the expansion of the sense of lacunar components, which is filled by information in the paratexts in general.

In a broad analysis of the editions adopted here as corpus, different characteristics and styles are found, both in the textual content of the translation itself and in what concerns the paratexts of the publications. Theoretical questions, referring to facts of linguistic, anthropological, spatial and temporal, and cultural nature must also be considered in the translation of literary works. The focus of this research is not to assess who made the best translation, or what form is the most appropriate, if only for the simple fact of the infeasibility of any attempt. The purpose here was to present the importance and applications of paratexts and their respective (para)translations as an indispensable resource for understanding the work of translating into other languages, as the case discussed on Genji Monogatari's translations from ancient Japanese into English.

\section{References}


ARNTZEN, S. "Getting at the language of The Tale of Genji through the Mirror of Translation." Approaches to Teaching Murasaki Shikibu's The Tale of Genji. New York: The Modern Language Association of America, 1993, pp.31-40.

BERMAN, A. La traduction et la lettre: ou l'auberge du lointain. Paris: Seuils, 1991.

BRITTO, P. H. “O tradutor como mediador cultural”. In: Synergies - Brésil: Littératures et politiques, langues et cultures - Traversées francobrésiliennes, n. spécial 2. São Paulo: Humanitas - FFLCH/USP, 2010.

EVEN-ZOHAR, I. Polysystem Studies. Tel Aviv: The Porter Institute for Poetics and Semiotics, and Durham: Duke University Press, 1990.

GENETTE, G. Paratexts: thresholds of interpretation. Cambridge: Cambridge University Press, 1997.

HIROSE, I. An Introduction to The Tale of Genji. Translated by Susan Tyler. Tokyo: University of Tokyo Press, 1989.

LYRA, R. M. O. T. “Explicar é preciso? Notas de tradutor: quando, como e onde". In: Fragmentos. Universidade Federal de Santa Catarina, Vol.8, n.1, 1999, pp.73-87. Retrieved from:

https://periodicos.ufsc.br/index.php/fragmentos/article/view/6039/5609. Acessed on 05 may 2019.

MIDORIKAWA, M. “Coming to Terms with the Alien: Translations of Genji Monogatari." In: Monumenta Nipponica. Sophia University, Vol. 58, n. 2, 2003, pp. 193-222. Source: http://www.jstor.org/stable/25066214. Acessed on 05 may 2019.

ORSI, M. T. “A padronização da linguagem: o caso japonês”. O Romance: a cultura do romance. Translated by Denise Bottmann. São Paulo: Cosac Naify, 2009.

PUETTE, W. J. The Tale of Genji - a reader's guide. Tokyo: Tuttle Publishing, 1983.

SEIDENSTICKER, E. G. The Tale of Genji - Murasaki Shikibu. New York: Alfred A. Knopf, 1992.

SETOUCHI, J. 源氏物語 Genji Monogatari. Vol. 1. Tokyo: Kodansha, 1996. 
SETOUCHI, J.; Keene, D.; Horton, H. M. The Tale of Genji: Scenes from the world's first novel (Illustrated Japanese Classics). United States: Kodansha, 2001.

SHIRANE, H. Envisioning The Tale of Genji - Media, Gender, and Cultural Production. New York: Columbia University Press, 2008.

TOURY, G. Descriptive Translation Studies and Beyond. Amsterdam: Benjamin, 1995.

TYLER, R. The Tale of Genji - Murasaki Shikibu. New York: Viking, 2001. WALEY, A. The Tale of Genji: a novel in six parts - Lady Murasaki. New York: The Modern Library, 1993.

YUSTE FRÍAS, J. Traducción y paratraducción de la literatura infantil y juvenil. In: Tradución e Política editorial de Literatura infantil y xuvenil. Colección Tradución \& Paratradución. Vigo: Universidade de Vigo, Servizo de Publicacións, D.L., 2006, pp.189-201.

. Paratextual Elements in Translation: Paratranslating Titles in Children's Literature. In: Translation Peripheries. Paratextual Elements in Translation. Frankfurt am Main, Berlin, Bern, Bruxelles, New York, Oxford, Wien: Peter Lang, 2012, pp.117-134.

. Paratextualidade e Tradução: a Paratradução da Literatura Infantil e Juvenil. Translated by Gisele Tyba Mayrink Orgado. In: Cadernos de Tradução. Universidade Federal de Santa Catarina, vol.2, n.34, 2014.

\begin{abstract}
This paper presents some of the first translations into English of the classic work of Japanese literature Genji Monogatari, which allowed readers in the western world to access this literary classic. The framework for this analysis is guided by Toury (1995) and Berman (1991), who discuss the role of the translator as an (inter)cultural mediator. Some paratextual elements and their translations will also be considered, based on the theoretical and methodological guidelines of Genette (1997) and Yuste Frías (2006; 2012).
\end{abstract}

Keywords: Genji Monogatari; Japanese Literature; English Translation; (Para)Translation. 


\section{Resumo}

Este artigo apresenta algumas das primeiras traduções para a língua inglesa da milenar obra clássica japonesa Genji Monogatari, o que permitiu aos leitores do ocidente ter acesso a este clássico literário. As considerações acerca da análise são norteadas pelos teóricos Toury (1995) e Berman (1991), que discutem o papel do tradutor como mediador (inter)cultural. Alguns elementos de natureza paratextual, bem como suas traduções, serão também considerados, com base nas orientações teóricas e metodológicas de Genette (1997) e Yuste Frías (2006; 2012).

Palavras-chave: Genji Monogatari; Literatura japonesa; Tradução Inglesa; (Para)Tradução. 